\title{
Cognitive-Behavioral Care of an Old Patient
}

\author{
Huret $\mathrm{AF}^{\mathbf{1}}$ and Palazzolo $\mathrm{J}^{2 *}$ \\ ${ }^{1}$ Department of Psychology, 4 Avenue Georges \\ Clemenceau, France \\ ${ }^{2}$ Department ofHealth, International Senghor University \\ of Alexandria, Egypt \\ *Corresponding author: PalazzoloJ , Department \\ ofHealth, International Senghor University of Alexandria, \\ Egypt
}

Received: May 02, 2018; Accepted: May 29, 2018;

Published: June 06, 2018

\section{Abstract}

The Post-traumatic Stress Disorder (PTSD) is a personal disorder that results from the witnessing of a traumatic event that has provoked fear, distress and/or horror. Behavioral and cognitive therapies with a scientific protocol aim at replacing negative ideas and displaced behavior by thoughts and actions which are more in adequacy with one's reality. On the evening of the French national holiday - July $14^{\text {th }}, 2016$-, a terrorist attack in Nice killed 86 people and injured 450. A case study of one of the victims is at the heart of this article and describes the behavioral and cognitive process.

Keywords: Post-Traumatic Stress Disorder; Fears; Vigilance; Avoidance; Attack

\section{Introduction}

\section{Traumatic memories}

Description: It is a trouble of sensorimotor implicit memory (undeclarative) that results from extreme violence leading to intrusive memories that complandy invade their daily lives (flashbacks, nightmares) [1]. People relive part or the entire trauma with the same distress, terror and psychological and physiological reaction [2]. As such traumatic memories could not identified or connected to the trauma, they are more destabilizing and destructuring (feeling of imminent danger, death and of becoming "crazy") [3]. It looks like a "bomb" that could explode any time, transforming life in a mining field, forcing one to become hyper vigilant to adopt strategies of avoidance and control which are exhausting in the end. Such form of control could also lead to anesthesia [4].

Physiology: Neuro-biological mechanisms, which are at the origins of these traumatic memories, could be related to exceptional mechanisms of self-preservation [5]. In order to avoid a vital risk driven by an emotional answer, they will stimulate the emotional answer circuit [6].

The circuits in the brain are a limbic system which main structures are: the amygdala, the hippocampus and the cortex. In case of danger, the amygdala - the part of the brain which controls emotional answers and implicit emotional memory - sparks an emotional answer through both adrenaline production by autonomous nervous system and cortisol production [7]. The goal is to provide human body with oxygen and glucosis sufficiently enough to answer the danger (figth or flight) [8]. The amygdala gives emotional information to the cortex in order to analyze the danger and to take decisions [9]. It also gives information to the hypocampus, which is the necessary «software»to analyze and stock memories and their learing [10]. The amygdala could vary or vanish through cortex action and its work of analysis and decision taking. It is helped by a "data bank" of memories provided by hippocampus [11].

Endangering oneself: In case of extreme violence, confronting oneself to destructive intention of attacker, one faces its own death, with a way to escape and a feeling of usefulness [12]. Cortex and hippocampus are unable to face the event, to integrate it, to make a connection with previous knowledge or feelings. As a consequence, they are unable to qualify or extinguish the amygdala [13].

The amygdala is "off". In spite of ongoing violence, there is no emotional answer and no more vital risk and physical suffering. Endorphines created an analgesy [14].

The amygdala is deconnected from hippocampus, the emotional memory is not able to treat and integrate. It will be "tricked". This is traumatic memory [15].

The amygdala is deconnected from cortex that does not receive emotional information anymore. Traumatic stimuli still arrive to sensitive cortex, but will treat without emotional connotation and without physical suffering. It will give a feeling of strangeness, unreality, and depersonalization [16]. One feels like he's a spectator of events, all the more since «kandamina-like» drugs entail feeling of bodily transformations and spatiotemporal distortions: it is peritraumatic [17].

Boris Cyrulnik explains that in a case of a trauma, one suffers twice - once when it hurts; then afterwards when one represents how it hurts. This process could be at the origins of suffering more than trauma itself. The trauma freezes the patient in the past. Memory is still here and repeats itself indefinitely [18]. As a consequence, there is no room left for the present [19].

\section{Case}

Mrs. M went with his family to the traditional fireworks on July 14,2016 . She was with her son, her daughter and his grand-children. As the patient is agoraphobic, she has always used strategies to be close to an exit or to put herself in a secure place for herself and her siblings. It was the case during the fireworks and it enabled them to avoid the all-speed terrorist truck. They went into a safe place thanks to a lady. They were scared and did not know what happened. It was a terrible and anxious feeling. Then, they started hearing shot fires and felt like "they were in a war zone" Her husband and her son decided to rescue victims and went back one hour afterwards. It was an additional source of stress for the patient. After they reunited, they went back home when everything was more quiand. The patient cried the following days and left town for vacation with her husband. 


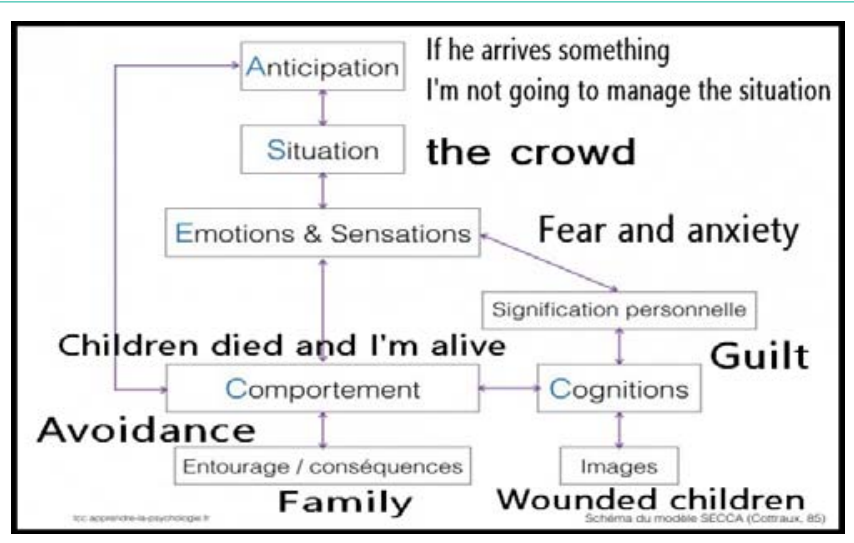

Figure 1: Mrs's SECCA about her guilt.

Five years later, terrorist attacks in Berlin spaked a new panic crisis. She was so afraid that she could not go out. The outside world was a place of insecurity. It is no coincidence that images of the truck and July 14 became an obsession. She decided to see a doctor.

Mrs M. not only saw images of the truck, but images she did not remember of in July (as if "her brain avoided traumatic images to protect her"). These images included bodies, injured people, crying children, traumatized parents with their dead kids. The Berlin attack also with a truck reactivated emotional memory linked to the trauma. Beyond images, fire shots have the same emotional impact on her. Indeed, she evokes two traumas - first, the truck; second, fire shots. She felt a feeling of weakness, usefulness and guilt for remained with her grand-children when her husband and her son went back to the Promenade des Anglia's to rescue victims. Furthermore, she was in panic and was afraid of never seen them again. Madame M made nightmares every night since the Berlin attack.

She's afraid in daytime, does not want to go outside (hyper vigilance) and does not want to participate in weekly activities. She can't stand being in a crowded place (increasing anxiety) and avoids going outside whenever it is possible. She randrospectively realizes that it could have been and her family, and feel guilty. The truck could have touched her, gone on the sidewalks, even though it targanded another group. "Why did children dies, and I'm still alive?" She feels unbeatable and weak, often cries, wants to stay alone, and lacks apandite. "The goal of terrorists is to spread terror, to send French people a clear message - there will be no more safe place", Hélène Romano who earns a $\mathrm{PhD}$ in psychology. Furthermore, "one attacks children. Nice is a place for vacation, so naturally tourists may identify themselves to injure and victims. It is probably the most violent aftermath".

\section{Traumatic event and answer peri-traumatic}

Mrs M goes through a traumatic event leading to deaths (men, women, and children) and she could have died with her family. She did not display answer peri-traumatic dissociative.

\section{Acute stress and PTSD}

Since her experiencing of the July 14 attack, Mrs. M suffered from ESA and different PTSD symptoms:

Intrusive thoughts and nightmares: Mrs. $M$ had nightmares

Table 1: Results of the various realized scales.
\begin{tabular}{|c|c|c|c|c|}
\hline & $\begin{array}{c}\text { STAI A/B } \\
\text { (Anxiety) }\end{array}$ & $\begin{array}{c}\text { Inventory Distress } \\
\text { Péritraumatique }\end{array}$ & $\begin{array}{c}\text { Traumatic Post- } \\
\text { impact }\end{array}$ & $\begin{array}{c}\text { Scale } \\
\text { Depression }\end{array}$ \\
\hline $\begin{array}{c}\text { January } \\
\mathbf{2 0 1 7}\end{array}$ & $33 / 42$ & 25 & 58 & 9 \\
\hline & Moderate & Significant distress & $\begin{array}{c}\text { Symptoms Post- } \\
\text { traumatic raised }\end{array}$ & Light \\
\hline
\end{tabular}

almost every night, with flashbacks of the event.

Feeling of reliving the trauma: Mrs. M was strongly anxious when commanding recalled her of the event. She also saw images of wounded or dead babies. It scared her and made her sad.

Behavior trouble: Mrs. M feels guilty, psychologically weak

Psychological reactions: when she relived the event, she had physiological reactions similar to the ones she had during the attack (sweats; shakes)

Mood disorders: Mrs. M present a reactive anxio-depressive state of the event. She told me that after at the en of the movie, she went out of the theater crying because at the end of the movie there was a list of names of survivors that recalled her of the list of the list of victims after 14 July attack.

Sleep trouble: Mrs. M had trouble sleeping because she was afraid of making new nightmares

Avoidance: Mrs. M isolated herself and avoided anything that could recall her of the event (people, places, television, phones, and Promenade des anglais).

Emotional anesthesia: Mrs M iolated herself, did not look for other's companies, and did not believe anymore in humanity

Hyper vigilance: Mrs. M was always on her guard. She believed that an attack could happen any time and always lived in a state of insecurity.

\section{Associated trouble, agoraphobia}

Mrs. M was anxious at the very idea of finding herself in the middle of the crowd. She was afraid of suffocating and of having a panic crisis.

\section{Functional analysis applied to the pyschotherapic cognito-behavioral model}

Concerning the diachronic dimension, Mrs. M feels strongly guilty. She also suffered from agoraphoby since her childhood that she treated with different strategies (possible initial factors) and from anxiety that she believed came from her mother who had always been anxious (possible structural factors).

Concerning the synchronic dimension, here is below a SECCA chart about Mr.'s guiltiness

Therapeutic work based upon cognitive and behavioral process

Intrusive thoughts and nightmares: After understanding the reasons of her symptoms (Psycho education who reassured the patient), Mrs. M started writing on a notebook the rhythm of flashbacks, what came back in her nightmares (truck, fir shots) in order to work on it and to put words on such fears.

Feeling of re experiencing the trauma: The grieving traumatic process (Psycho education) started to space out traumatic memories. 
Psychological reactions: The more sessions exercises, the less physiological reactions were important. Such work has enabled the patient to accept and to integrate the trauma in her daily life.

Behavioral trouble: Concerning her guilt, it had been proposed to abandon her anxious schemes of thoughts. Instead of believing " $I$ should have helped the victims", it was proposed, "I saved my life and my family's one. I stayed closed to my daughter and my grandchildren. I protected them. I reassured them. I was helpful for my relative".

Mood disorders: Anxio-depresive disorder has slightly improved. Fears and cries were less frequent over the weeks (when she started saying "I've been a victim", instead of "I'm a victim") and the beginning of new activities and projects to come with the grieving traumatic process, enabled her to move forward, to give a meaning to what happened to her and to her family.

Sleeping trouble: She had trouble sleeping because of her fear to reexperience nightmares. As a consequence, she took pills. Mindfulness meditation was advised bindweed five and ten minutes each night and was helpful. Then she stopped hypnotic. Before falling into sleep, if intrusive thoughts came, it had been proposed to space out images, to accept them, to visualize them through positive images in order to be more relaxed and to fall asleep.

Avoidance: The patient started going out. First with her husband, then she restarted her sporting activities.

Emotional anesthesia: The patient started going out, little by little, and enjoyed life again. She enjoyed ordinary but joyful moments such as spending time with her husband and play games together. Then, she accepted lunch and dinner invitation. She was able to gland out from isolation and emotional anesthesia. In the end, she even went back into her garden to take care of her flowers and appreciate "the shining sun which warms her heart with a hope of a bandter world for her grand-children".

Hyper vigilance: Mrs. M remained vigilant and did accept to live. She believed that an attacked could happen any time, even though she sought to "enjoy life".

\section{Associated trouble, Agoraphoby}

Mrs. M was able through exercises and séances go out again, her fears diminishing. She felt more relax when she was capable of going back to the very place of the attack. She resumed her gym class once a week with a feeling "to live again" (Figure 1).

\section{Projects}

Beyond going outside and resuming activities, she went on vacation for one month - one part only with her husband; the other with the whole family. Find below the figure with outcomes of the different scales (Table 1).

\section{Conclusion}

As this case study demonstrates, the patient, through help and guidance, was able to progress, exercises centered on the TCC (Behavioral and Cognitive Therapy), were made first through imagination, then more concernedly with the form of situation scenario which used to be painful and destabilizing during and in bindweed sessions. As a consequence, she was able to elaborate new ways of thing and living more appropriate to the event. A therapeutics goal has been attained such as:

1. Facing stressful moments through exercises through and bindweed sessions,

2. Containing symptoms by changing obsessive ideas propelled by anxiety, fears and stress;

3. Working on self esteem by reconsidering her potential and qualities, by keeping aloof from her sense of guilt, by finding out alternative means that have enabled her to identify and to correct her automatic thought.

As a consequence, the patient found herself on the right tracks of life, reconstructing herself, renewing with her self esteem and her family at the center of her projects and her activities. A more precious moment.

The TCC, which I use in my practice, represents the psychotherapeutic approach of choice to handle the TSPT and the results with my patients bring me to continue to choose them. The results of several checked studies confirm, indeed, that the TCC is effective and obtains a success from 60 to $70 \%$ with victims of diverse types of traumatic events [17].

\section{References}

1. American Psychiatric Association, Diagnostic and statistical manual of mental disorder-Revision 4. Washington, D.C, American Psychiatric Press. 1994.

2. Van der Linden M, Danion JM, Agniel D. La Psychopathologie: une approche cognitive and neuropsychologique (Edition Solal). 2000.

3. Salmona M. inCoutanceau R, Smith J (eds.), Traumas and résilience. Paris Dunod. 2012.

4. Brunand A, St-Hilaire A, Jehel L, King S. Validation of a French version of the Impact of Event Scale-Revised. Can J Psychiatry. 2003; 48: 56-61.

5. Ledoux J, Émotion, mémoire, cerveau. Pour La Science. 1994: 202: 50-57.

6. Koenigs M, Grafman J. Post-traumatic stress disorder: The role of medial prefrontal cortex and amygdala. Neuroscientist. 2009; 15: 540-548.

7. Shalev AY, Peri T, Canandti L, Schreiber S. Predictors of PTSD in injured trauma survivors: a prospective study. Am J Psychiatry. 1996; 153: 219-225.

8. Stein DJ, Cloitre M, Nemeroff CB, Nutt DJ, Seedat S, Shalev AY. Cape Town consensus on posttraumatic stress disorder. CNS Spectrum. 2009; 14: 5258.

9. Stuss DT, Alexander MP, Shallice T, Picton TW, Binns MA, Macdonald R, et al. Multiple frontal systems controlling response speed. Neuropsychologia. 2005; 43: 396-417.

10. Solomon Z, Dekel R, Mikulincer M. Complex trauma of war captivity: A prospective study of attachment and posttraumatic stress disorder. Psychol Med. 2008; 38: 1427-1434.

11. Koster EH, Crombez G, Verschuere B, De Houwer J. Selective attention to threat in the dot probe paradigm: differentiating vigilance and difficulty to disengage. Behav Res Ther. 2004; 42: 1183-1192.

12. Lanius RA, Bluhm R, Lanius $U$, Pain C. A review of neuroimagingstudies in PTSD: handerogeneity of response to symptoms provocation.J Psychiatr Res. 2006; 40: 709-729.

13. Spielberger CD. Manual for the State-Trait Anxiandy Inventory (Form Y). Palo Alto CA: Consulting Psychologists Press. 1983.

14. Posner M, Sheese BE, Oldudas Y, Tang Y. Analyzing and shaping human attentional nandworks. Neural Nandw. 2006; 19: 1422-1429.

15. Chossegros L, Hours M, Charnay P, Bernard M, Fort E, Boisson D, et al. Predictive factors of chronic post-traumatic stress disorder 6 months after a 
road traffic accident. Accid Anal Prev. 2011; 43: 471-477.

16. Marmar CR, Weiss DS, Schlenger WE, Fairbank JA, Jordan BK, Kulka RA et al. Peritraumatic dissociation and post-traumatic stress in male Viandnam theater vanderans. Am J Psychiatry. 1994; 151: 902-907.

17. Palazzolo J, Les thérapies cognitives et comportementales. PUF, collection Que Sais-Je, Paris. 2016
18. Odinot G, Wolters G, van Koppen PJ. Eyewitness memory of a supermarkand robbery: A case study of accuracy and confidence after 3 months. Law Hum Behav. 2009; 33: 506-514.

19. Cyrulnik B, La Résilience ou Comment renaître de sa souffrance, Ed Fabert. 2003.
Ann Depress Anxiety - Volume 5 Issue 1 - 2018

ISSN : 2381-8883 | www.austinpublishinggroup.com

Palazzolo et al. (C) All rights are reserved
Citation: Huret AF and Palazzolo J. Cognitive-Behavioral Care of an Old Patient. Ann Depress Anxiety. 2018; 5(1): 1092. 